\title{
Prevalence of Anti-HBc Antibodies among HBsAg Negative Individuals and Its Association with Occult Hepatitis B
}

\author{
Anitha Madhavan ${ }^{1}$ Arun Sachu ${ }^{2}$ Anu Kumar Balakrishnan ${ }^{3}$ Sobha Balakrishnan ${ }^{1}$ \\ Jayalakshmi Vasudevapanicker ${ }^{1}$
}

${ }^{1}$ Department of Microbiology, Government TD Medical College,

Address for correspondence Arun Sachu, MD, Department of Alappuzha, Kerala, India

${ }^{2}$ Department of Microbiology, Believers Church Medical College, Microbiology, Believers Church Medical College, Thiruvalla, Kerala Thiruvalla, Kerala, India

${ }^{3}$ National Institute of Virology, Alappuzha, Kerala, India

J Lab Physicians 2021;13:1-5.

\begin{abstract}
Keywords

- Anti-hepatitis B core total antibody

- HBV DNA

- Occult hepatitis B

Introduction Hepatitis B virus (HBV) infection is an endemic in many Asian countries, and among the major routes of transmission, transfusion is the one that should be prevented. Occult HBV infection (OBI) is defined as the presence of HBV DNA in the absence of detectable HBsAg, with or without anti-HBV antibodies. The aim of this study was to detect the prevalence of anti-HBc total antibodies among the HB surface antigen ( $\mathrm{HBsAg}$ ) negative individuals by way of enzyme-linked immunosorbent assay (ELISA), and detect the presence of HBV DNA among the anti-HBc seropositives by polymerase chain reaction (PCR). Anti-HBs among the HBV DNA positives were also found out by enzyme-linked fluorescent assay (ELFA).

Materials and Methods A total of 910 serum samples was subjected to initial screening for HBsAg by MERILISA HBsAg ELISA kits. The anti-HB core ( $\mathrm{HBC})$ total antibody titer was evaluated using MONOLISA ELISA (Biorad) kits. If found negative, the samples were discarded. If found positive, the samples underwent HBV DNA testing by nested PCR. Antibody to hepatitis B surface antigen (anti-HBs) was calculated among the DNA positives by ELFA.

Results A total of 133 samples were positive for anti-HBC total antibody, resulting in an overall prevalence of $14.6 \%$. Overall prevalence of HBV DNA among the anti-HBC seropositives was $2.2 \%$.

Conclusion Among the three HBV DNA positive patients, two belonged to the preoperative screening group, which is an alarming situation. Screening of blood for $\mathrm{HBsAg}$ has reduced the incidence of posttransfusion hepatitis, but HBV still remains the major source of transfusion transmitted infection in India.
\end{abstract}

\section{Introduction}

Hepatitis B virus (HBV) infection is an endemic in many Asian countries, but highly effective vaccination programs in some countries have shifted this pattern toward intermediate or low endemicity. India falls in an intermediate

published online

May 19, 2021
DOI https://doi.org/

10.1055/s-0041-1723046 ISSN 0974-2727. endemic zone (prevalence of $2-7 \%$, with an average of $4 \%$ ), with a disease burden of approximately 50 million. ${ }^{1}$ Blood transfusion and unsafe therapeutic injections continue to be important modes of transmission of HBV. For several decades, laboratories have relied on serological screening of

(c) 2021. The Indian Association of Laboratory Physicians.

This is an open access article published by Thieme under the terms of the Creative Commons Attribution-NonDerivative-NonCommercial-License, permitting copying and reproduction so long as the original work is given appropriate credit. Contents may not be used for commercial purposes, or adapted, remixed, transformed or built upon. (https://creativecommons.org/licenses/by-nc-nd/4.0/).

Thieme Medical and Scientific Publishers Pvt. Ltd. A-12, 2nd Floor, Sector 2, Noida-201301 UP, India 
patients using sensitive HBsAg assays to detect HBV infection. Some countries have also adopted anti-HB core (HBc) assays to detect chronic carriers with low-level viremia and who lack detectable HBsAg. ${ }^{2}$ Despite the screening methods, it was observed that $\mathrm{HBV}$ infection can still occur even in the absence of HBsAg, which is known as occult HBV infection (OBI). ${ }^{3}$ This phenomenon is becoming increasingly recognized in several clinical settings worldwide. OBI is simply defined as presence of circulating HBV DNA among those with serologically undetectable hepatitis B surface antigen (HBsAg) negatives. OBI may be antibody (anti-HBc alone or together with anti-HBs) positive (seropositive OBI), or antibody negative (seronegative OBI). ${ }^{4}$ The Taormina Consensus Conference in 2008 further defined "OBI" as the "presence of HBV DNA in the liver of individuals testing HBsAg negative with currently available assays" and introduced a cutoff value for serum HBV DNA $(<200 \mathrm{IU} / \mathrm{mL}) .^{5}$ Studies on a large set of blood donors using NAT (nucleic acid testing) confirmed this phenomenon of OBI and formed the basis of mandatory NAT for transfused blood units in many developed countries. Such a testing algorithm is still not incorporated in many laboratories in developing countries including India. ${ }^{6,7} \mathrm{OBI}$ can cause fulminant hepatitis. It is associated with development of hepatocellular carcinoma and cryptogenic liver disease. It can also affect the disease progression of chronic hepatitis $C$ virus (HCV) patients. ${ }^{8,9}$

In India, $\mathrm{HBV}$ infection is diagnosed by detection of $\mathrm{HBsAg}$. Detection of anti-HBc antibody is rarely done as it is not mandatory. ${ }^{10}$ In India, blood reactive for anti-HBc can be transfused to patients. In India, it is recommended that blood with high anti-HBc titer are rejected, but titer is not defined..$^{11}$ Patients with occult HBV infection, who lack detectable HBsAg with anti-HBc positivity and HBV DNA, are a potential source of HBV infection. ${ }^{12}$ HBV can also be transmitted when liver is transplanted from a HBsAg negative, anti-HBc positive patient, which proves that liver harbors infectious HBV in some patients negative for $\mathrm{HBsAg}$ but positive for anti-HBc. ${ }^{13}$ OBI carriers with high anti-HBs levels are unlikely to transmit the infection, whereas those with "anti-HBc only" might transmit the infection. ${ }^{14}$ The aim of this study was to detect the prevalence of anti-HBc total antibody among the $\mathrm{HBsAg}$ negative individuals by enzyme-linked immunosorbent assay (ELISA), and detect the presence of HBV DNA among the anti-HBc seropositives by polymerase chain reaction (PCR). Anti-HBs among the HBV DNA positives were also found out by enzyme-linked fluorescent assay (ELFA).

\section{Materials and Methods}

This study was conducted from January 2018 to December 2018 and the proposal for the study was approved by the Ethical Committee of Government TD Medical College. Serum samples were collected from patients who were more than 18 years old belonging to the following groups after obtaining informed consent: preoperative screening patients $(n=517)$, human immunodeficiency virus (HIV) positives $(n=223)$, patients on hemodialysis $(n=108)$, HCV positives $(n=42)$, and alcoholic liver disease patients $(n=20)$. The overall sample size was 910 .

Study subjects who were not willing to participate in the study, patients below 18 years of age, HBsAg seropositive patients, and patients having overlap between two categories were excluded from the study.

Under aseptic precaution, $5 \mathrm{~mL}$ blood was collected from the cubital fossa through venipuncture by a phlebotomist. The serum was separated and subjected to initial screening for HBsAg marker by MERILISA HBsAg ELISA kits. The anti-HBC total antibody titer was evaluated using MONOLISA ELISA (Biorad) kits. If found negative, the samples were discarded. If found positive, the samples underwent HBV DNA testing by nested PCR. The DNA positive samples were subjected to anti-HBs titer estimation by ELFA. All relevant patient details were collected from medical records. In this study, OBI was calculated on the basis of prevalence of HBV DNA among HBsAg negative individuals who were positive for Anti-HBC total antibody. Antibody to HBsAg was estimated only among the samples positive for HBV DNA.

\section{Results}

This study was conducted on 910 patients divided into different groups. Age-wise distribution show that maximum number of samples were received from patients belonging to the 41 to 60 -year age group (- Table 1). Distribution of anti-HBc total

Table 1 Age wise distribution of patients in different groups

\begin{tabular}{|l|l|l|l|}
\hline Category & $20-40$ years & $41-60$ years & More than 60 years \\
\hline $\begin{array}{l}\text { Preoperative screening patients } \\
(n=517)\end{array}$ & 134 & 236 & 147 \\
\hline $\begin{array}{l}\text { HIV positives } \\
(n=223)\end{array}$ & 62 & 103 & 58 \\
\hline $\begin{array}{l}\text { Patients on hemodialysis } \\
(n=108)\end{array}$ & 34 & 42 & 32 \\
\hline $\begin{array}{l}\text { HCV positives } \\
(n=42)\end{array}$ & 18 & 14 & 10 \\
\hline $\begin{array}{l}\text { Alcoholic liver disease patients } \\
(n=20)\end{array}$ & 2 & 12 & 6 \\
\hline Total $(n=910)$ & 250 & 407 & 253 \\
\hline
\end{tabular}

Abbreviations: HCV, hepatitis C virus; HIV, human immunodeficiency virus. 
antibody among the study group showed that a total of 133 samples were positive for anti-HBc total antibody (- Table 2), with an overall prevalence of $14.6 \%$. HBV DNA distribution among the anti-HBc total positives ( - Table 3 ) showed that among the three positives, two were from the preoperative screening group and the other was an HCV positive patient. The prevalence of $\mathrm{OBI}$ among the anti-HBc seropositives was $2.2 \%$. The overall findings of the study are shown in - Table 4.

Anti-HBs was tested by ELFA in two among the HBV DNA positives belonging to the preoperative screening group and both were found to be $<10$ ( $3 \mathrm{mUI} / \mathrm{mL}$ and $7 \mathrm{mUI} / \mathrm{mL}$, respectively). Anti-HBs was not tested in one of the HBV DNA positives due to lack of adequate sample.

\section{Discussion}

The majority of research works on OBI done in India and globally are on blood donors. In this study, the majority of samples were obtained from preoperative screening patients (56.8\%) and others included HIV patients (24.5\%), patients on hemodialysis (11.87\%), HCV positive patients (4.6\%), and

Table 2 Distribution of anti-HBc total positivity among different groups

\begin{tabular}{|l|l|l|}
\hline Category & $\begin{array}{l}\text { No. of } \\
\text { positives } \\
(n=133)\end{array}$ & Percentage \\
\hline $\begin{array}{l}\text { Preoperative screening patients } \\
(n=517)\end{array}$ & 70 & 13.5 \\
\hline $\begin{array}{l}\text { HIV positives } \\
(n=223)\end{array}$ & 42 & 18.8 \\
\hline $\begin{array}{l}\text { Patients on hemodialysis } \\
(n=108)\end{array}$ & 14 & 13 \\
\hline $\begin{array}{l}\text { HCV positives } \\
(n=42)\end{array}$ & 5 & 11.9 \\
\hline $\begin{array}{l}\text { Alcoholic liver disease patients } \\
(n=20)\end{array}$ & 2 & 10 \\
\hline
\end{tabular}

Abbreviations: anti-HBc, Hepatitis B core antibody; HCV, hepatitis $C$ virus; HIV, human immunodeficiency virus.

Table 3 Distribution of HBV DNA positivity among the anti$\mathrm{HBC}$ total positives

\begin{tabular}{|l|l|l|}
\hline Category & $\begin{array}{l}\text { No. of } \\
\text { positives } \\
(n=3)\end{array}$ & Percentage \\
\hline $\begin{array}{l}\text { Preoperative screening patients } \\
(n=70)\end{array}$ & 2 & 2.9 \\
\hline $\begin{array}{l}\text { HIV positives } \\
(n=42)\end{array}$ & 0 & 0 \\
\hline $\begin{array}{l}\text { Patients on hemodialysis } \\
(n=14)\end{array}$ & 0 & 0 \\
\hline $\begin{array}{l}\text { HCV positives } \\
(n=5)\end{array}$ & 1 & 20 \\
\hline $\begin{array}{l}\text { Alcoholic liver disease patients } \\
(n=2)\end{array}$ & 0 & 0 \\
\hline
\end{tabular}

Abbreviations: anti-HBc, Hepatitis B core antibody; HCV, hepatitis $C$ virus; HIV, human immunodeficiency virus. alcoholic liver disease patients (2.2\%). The probability of detecting HBV DNA is highest among individuals who are anti-HBc positive and anti-HBs negative..$^{15}$ Anti-HBc total has been used a surrogate marker for OBI. Prevalence of Anti-HBc in our study was $14.6 \%$, which is concordant with the findings in other studies in India (10.2-58.8\%). ${ }^{16}$ Accurate diagnosis of OBI requires HBV DNA PCR assay, but it is not cost-effective. Studies from different parts of India found OBI ranging from 3.9\% in Kolkata (eastern India) and 0.78\% in New Delhi (northern India) to $0.05 \%$ in Chandigarh (north-western India) and $0.15 \%$ in Vellore (southern India). ${ }^{17-20}$ The prevalence of OBI among the anti-HBc seropositives was found to be $2.2 \%$ in our study. The variation in the prevalence of $\mathrm{OBI}$ is probably due to the use of HBsAg assays with varying sensitivity, prevalence of $\mathrm{HBV}$, and the type of the population in which the study was done. ${ }^{21}$ Among the three HBV DNA positive cases in our study, two were from patients who underwent routine preoperative screening. This is an alarming finding which further justifies the need to include NAT for screening of hepatitis B, especially in blood banks.

Out of 910 samples, 223 were collected from HIV positive patients. The prevalence of anti-HBc total antibody among the HIV positives was $18.8 \%$, but none of them were positive for HBV DNA. Anti-HBc total antibody prevalence among the HIV positives was concordant with the findings from a study in eastern India which showed a prevalence of $17.8 \% .^{22}$ A study conducted by Gupta et al among HIV positives showed that $35.8 \%$ of the $\mathrm{HbsAg}$ negative individuals showed presence of anti-HBc total antibody. The same study showed presence of HBV DNA in $45.3 \%$ of the samples who were negative for HBsAg but positive for other serological markers. ${ }^{23}$ In our study, HBV DNA was not detected in any of the HIV patients which was a surprising finding, whereas the study in eastern India showed a HBV DNA prevalence of $6.3 \%$. Our finding is concordant with findings of Nunez et al who did not find the presence of HBV DNA among any of the HIV positive cases. ${ }^{24}$ The reason for the absence of HBV DNA among HIV positives is unclear, but it could be due to the fact that most of the HIV positives in our study had higher CD4 cell counts. Stuart et al reported that OBI was more commonly found among the HIV positives with lower CD4 counts when compared with those with higher CD4 counts. ${ }^{25}$

Research works on OBI prevalence among hemodialysis patients showed varying range from $2.7 \%$ in Turkey ${ }^{26}$ to $50 \%$ in Iran. ${ }^{27}$ In our study, 14 (13\%) samples were positive for anti-HBc antibody among 108 hemodialysis patients but none of them were positive for HBV DNA. A study conducted

Table 4 Overall prevalence of anti-HBc and HBV DNA in the study

\begin{tabular}{|l|l|l|}
\hline Test & $\begin{array}{l}\text { No. of samples } \\
\text { tested }\end{array}$ & $\begin{array}{l}\text { No. of } \\
\text { positives }\end{array}$ \\
\hline Anti-HBc total ELISA & 910 & $133(14.6 \%)$ \\
\hline HBV DNA PCR & 133 & $3(2.2 \%)$ \\
\hline
\end{tabular}

Abbreviations: anti-HBc, Hepatitis B core antibody; ELISA, enzyme-linked immunosorbent assay, HBV, hepatitis B virus; HCV, hepatitis C virus; HIV, human immunodeficiency virus; PCR, polymerase chain reaction. 
by Jain et al found the prevalence of OBI among hemodialysis patients to be $4.9 \%$. Our finding is concordant with the studies conducted in Italy and Iran which did not detect the presence of HBV DNA among hemodialysis patients. ${ }^{28,29}$ The absence of HBV DNA among the hemodialysis patients is probably due to the HBV vaccination and the regular surveillance for hepatitis B in our hospital.

Prevalence of OBI has been reported to be very high among $\mathrm{HCV}$ positive patients. HBV activity may be impaired by coinfection with infectious agents like HCV. HCV core protein strongly inhibits HBV replication. Sood et al reported a prevalence of $10 \%$, whereas Cacciola et al reported a prevalence of $33 \% .^{30,31}$ Out of $42 \mathrm{HCV}$ positives, anti-HBc antibody was detected in five samples (prevalence 11.9\%, - Table 2). The HBV DNA prevalence among this category was found to be $20 \%$ ( Table 3). In our study, prevalence of anti-HBc antibodies was $10 \%$ among the 20 samples collected from alcoholic liver disease patients, but HBV DNA was not detected in these samples. This was discordant with the study conducted by Hashemi et al which showed an HBV DNA prevalence of $14 \%{ }^{32}$ This might be explained due to the small sample size of alcoholic liver disease patients in our study. The anti-HBs assay done on two out of three HBV DNA positive samples showed titers $<10 \mathrm{mIU} / \mathrm{mL}$. Varying anti-HBs immune levels among HBV DNA positives are reported in other studies, where $75 \%$ (Ismail et al) and 50\% (Keechilot et al) of the HBV DNA positives were found to be immune..$^{20,21}$

To conclude, the prevalence of anti-HBc antibody and the HBV DNA prevalence among anti-HBc positives was found to be $14.6 \%$ and $2.2 \%$, respectively. Among the three HBV DNA positive patients, two belonged to the preoperative screening group, which is an alarming situation. Detection of HBV DNA by NAT is the only way to completely rule out hepatitis $B$ infection. Nucleic acid amplification test (NAAT) results in our study show that $68 / 70$ (97.1\%) of the anti-HBc seropositives among the preoperative screening patients were negative for HBV DNA, which precludes us to use anti-HBc ELISA in routine screening.

Our study had a few limitations. Anti-HBc seropositives were not repeatedly tested to rule out false positivity. Anti-HBs was not performed in one of the HBV DNA positives due to inadequate sample. Viral load by real-time PCR was not done in any of the samples.

Financial Support

Nil.

\section{Conflicts of Interest}

None declared.

\section{Acknowledgments}

Authors would like to thank the National Institute of Virology, Kerala Unit, for providing all the facilities for performing the PCR and also the Department of Microbiology, Government Medical College, Alleppey, for all their support throughout the study.

\section{References}

1 Ray G. Current Scenario of Hepatitis B and Its Treatment in India. J Clin Transl Hepatol 2017;5(3):277-296

2 Busch MP. Should HBV DNA NAT replace HBsAg and/ or anti-HBc screening of blood donors? Transfus Clin Biol 2004;11(1):26-32

3 Allain JP. Occult hepatitis B virus infection. Hep B Annual 2005;2:14-30

4 Said ZN. An overview of occult hepatitis B virus infection. World J Gastroenterol 2011;17(15):1927-1938

5 Raimondo G, Allain JP, Brunetto MR, et al. Statements from the Taormina expert meeting on occult hepatitis B virus infection. J Hepatol 2008;49(4):652-657

6 Panhotra BR, Bahrani A, Joshi CS, ul Hassan Z. Occult hepatitis $B$ virus infection among anti-HBc positive blood donors: Necessitates substitution of screening by HBV NAT. J Infect 2005;51(3):263

7 Prati D, Gerosa A, Porretti L. Occult HBV infection and blood transfusion. J Hepatol 2006;44(4):818-, author reply 819

8 Giudice CL, Martinengo M, Pietrasanta P, et al. Occult hepatitis $B$ virus infection: a case of reactivation in a patient receiving immunosuppressive treatment for allogeneic bone marrow transplantation. Blood Transfus 2008;6(1):46-50

9 Shi Y, Wu YH, Wu W, Zhang WJ, Yang J, Chen Z. Association between occult hepatitis B infection and the risk of hepatocellular carcinoma: a meta-analysis. Liver Int 2012;32(2):231-240

10 Chattopadhyay S, Rao S, Das BC, Singh NP, Kar P. Prevalence of transfusion-transmitted virus infection in patients on maintenance hemodialysis from New Delhi, India. Hemodial Int 2005;9(4):362-366

11 Vyas GN, Algorithm for safe blood with regard to transfusion acquired infections. In: Sarin SK, Hess G, eds. Transfusion Associated Hepatitis. Diagnosis, Treatment and Prevention. New Delhi: CBS Publishers \& Distributors; 1998 462-478

12 Dreier J, Kröger M, Diekmann J, Götting C, Kleesiek K. Low-level viraemia of hepatitis $B$ virus in an anti-HBc- and anti-HBs-positive blood donor. Transfus Med 2004;14(2):97-103

13 Dickson RC, Everhart JE, Lake JR, et al; The National Institute of Diabetes and Digestive and Kidney Diseases Liver Transplantation Database. Transmission of hepatitis B by transplantation of livers from donors positive for antibody to hepatitis B core antigen. Gastroenterology 1997;113(5):1668-1674

14 Allain J-P, Mihaljevic I, Gonzalez-Fraile MI, et al. Infectivity of blood products from donors with occult hepatitis B virus infection. Transfusion 2013;53(7):1405-1415

15 Hollinger FB. Hepatitis B virus infection and transfusion medicine: scienceand theoccult.Transfusion 2008;48(5):1001-1026

16 Asim M, Ali R, Khan LA, Husain SA, Singla R, Kar P. Significance of anti-HBc screening of blood donors and its association with occult hepatitis B virus infection: Implications for blood transfusion. Indian J Med Res 2010;132:312-317

17 Chaudhuri V, Nanu A, Panda SK, Chand P. Evaluation of serologic screening of blood donors in India reveals a lack of correlation between anti-HBc titer and PCR-amplified HBV DNA. Transfusion 2003;43(10):1442-1448

18 Bhattacharya P, Chandra PK, Datta S, et al. Significant increase in HBV, HCV, HIV and syphilis infections among blood donors in West Bengal, Eastern India 2004-2005: exploratory screening reveals high frequency of occult HBV infection. World J Gastroenterol 2007;13(27):3730-3733

19 Makroo RN, Chowdhry M, Bhatia A, Arora B, Rosamma NL. Hepatitis B core antibody testing in Indian blood donors: A double-edged sword! Asian J Transfus Sci 2012;6(1):10-13

20 Ismail AM, Devakumar S, Anantharam R, et al. Low frequency of occult hepatitis B infection in anti-HBc seropositive blood 
donors: experience from a tertiary care centre in South India. Blood Transfus 2012;10(2):230-232

21 Keechilot CS, Shenoy V, Kumar A, et al. Detection of occult hepatitis $B$ and window period infection among blood donors by individual donation nucleic acid testing in a tertiary care center in South India. Pathog Glob Health 2016;110(7-8):287-291

22 Saha D, Pal A, Sarkar N, et al. Occult hepatitis B virus infection in HIV positive patients at a tertiary healthcare unit in eastern India. PLoS One 2017;12(6):e0179035

23 Gupta S, Singh S. Occult hepatitis B virus infection in ART-naive HIV-infected patients seen at a tertiary care centre in north India. BMC Infect Dis 2010;10:53

24 Núñez M, Ríos P, Pérez-Olmeda M, Soriano V. Lack of 'occult' hepatitis B virus infection in HIV-infected patients. AIDS 2002;16(15):2099-2101

25 Cohen Stuart JW, Velema M, Schuurman R, Boucher CA, Hoepelman AI. Occult hepatitis B in persons infected with HIV is associated with low CD4 counts and resolves during antiretroviral therapy. J Med Virol 2009;81(3):441-445

26 Yakaryilmaz F, Gurbuz OA, Guliter S, et al. Prevalence of occult hepatitis $B$ and hepatitis $C$ virus infections in Turkish hemodialysis patients. Ren Fail 2006;28(8):729-735
27 Aghakhani A, Banifazl M, Kalantar E, et al. Occult hepatitis $B$ virus infection in hemodialysis patients with isolated hepatitis B core antibody: a multicenter study. Ther Apher Dial 2010;14(3):349-353

28 Fabrizi F, Messa PG, Lunghi G, et al. Occult hepatitis B virus infection in dialysis patients: a multicentre survey. Aliment Pharmacol Ther 2005;21(11):1341-1347

29 Kalantari H, Ferdowsi F, Yaran M. Prevalence of occult hepatitis $B$ virus infection in hemodialysis patients in Isfahan, Iran. Adv Biomed Res 2016;5:151

30 Sood AK, Pangotra C, Manrai M. Prevalence of occult hepatitis B infection in patients visiting tertiary care hospital. Med J Armed Forces India 2016;72(2):140-144

31 Cacciola I, Pollicino T, Squadrito G, Cerenzia G, Orlando ME, Raimondo G. Occult hepatitis B virus infection in patients with chronic hepatitis $\mathrm{C}$ liver disease. $\mathrm{N}$ Engl J Med 1999;341(1):22-26

32 Hashemi SJ, Hajiani E, Masjedizadeh A, et al. Occult hepatitis B infection in patients with cryptogenic liver cirrhosis in southwest of iran. Jundishapur J Microbiol 2015;8(3):e16873 